Preparation and study of the physicochemical characteristics of multilayer polymer composites based on poly(ethyleneimine)stabilized copper nanoparticles and poly(sodium 2-acrylamide-2methyl-1-propanesulfonate)

B.S. Selenova ${ }^{1}$, A.Ye. Ayazbayeva ${ }^{1}$, A.V. Shakhvorostov ${ }^{2}$, S.K. Kabdrakhmanova ${ }^{1,3^{*}}$ S.Z. Nauryzova ${ }^{1}$, S.E. Kudaibergenov

${ }^{1}$ Satbayev University, Almaty, Kazakhstan ${ }^{2}$ Institute of Polymer Materials and Technology Almaty, Kazakhstan

${ }^{3}$ Scientific Center of Composite Materials, Almaty, Kazakhstan *E-mail: sanaly33@mail.ru
Multilayer films were synthesized from a complex of branched polyethyleneimine (PEI) with copper nanoparticles (PEI-CuNPs) and sodium poly-2-acrylamide-2-methyl1-propanesulfonate (PAMPSNa), applied layer-by-layer (LbL) on a solid support in an acidic medium. Protonation of the amino groups of PEI in an acidic medium increases the positive charge of the PEI-CuNPs system to $+43.5 \mathrm{mV}$ and promotes the formation of an interpolyelectrolyte complex between the positively charged PEI-CuNPs and the highly charged anionic polyelectrolyte PAMPS, the Z-potential of which was -141 mV. AFM images and SEM micrographs showed a uniform distribution of spherical copper nanoparticles in the homogeneous structure of the multilayer film. The optical characteristics and hydrodynamic dimensions of PEI-CuNPs indicate the formation of PEI-CuNPs nanoparticles with sizes of $60-300 \mathrm{~nm}$, with an average size of up to $100 \mathrm{~nm}$. Copper nanoparticles distributed uniformly in a multilayer PEI-CuNPs/PAMPS film may be of interest for applications in the field of membrane catalysis, biochips, sensor membranes, and controlled drug delivery.

Keywords: polyethylenimine; sodium poly-2-acrylamide-2-methyl-1propanesulfonate; complexes of PEI-Cu ${ }^{2+}$ and PEI-CuNPs; layer-by-layer (LbL) deposition multilayered thin films of PEI-CuNPs/PAMPS
Поли (этилениминде)

тұрақтандырылған мыс нанобөлшектері және поли (2-акриламидо-2-метил-1натрий пропансульфонаты) негізіндегі мультиқабатты полимерлік композит алу және

оның физикалық-химиялық сипаттамаларын зерттеу

Б.С. Селенова ${ }^{1}$, А.Е. Аязбаева ${ }^{1}$, А.В. Шахворостов ${ }^{2}$, С.К. Кабдрахманова ${ }^{1,3^{*}}$ С.3. Наурызова ${ }^{1}$, С.Е. Кұдайбергенов

${ }^{1}$ Satbayev University, Алматы, Қазақстан Полимерлік материалдар және технологиялар институты, Алматы, Қазақстан ${ }^{3}$ Композиттік материалдар ғылыми орталығы, Алматы, Қазақстан *E-mail: sanaly33@mail.ru
Қышқыл ортада қатты субстратқа layer-by-layer (LbL) әдісімен қабатпен жағылған мыс нанобөлшектері (PEI-CUNPs) және поли-2-акриламид-2-метил-1-натрий пропансульфонаты (PAMPSNa) бар тармақталған полиэтиленмин (PEI) кешенінің қатысуымен мүльти қабатты пленкалар синтезделді. PEI амин топтарының қышқыл ортада протондалуы PEI-CuNPs жүйесінің зарядын +43,5 mV-ге дейін арттырады және зарядталған PEI-CUNPS жоғары зарядталған анионды PAMPS полиэлектролит арасындағы интерполиэлектролит кешенінің пайда болуына ықпал етеді, -potential -141 mV-ге тең. ACM суреттері мен микрофотографиялары көп қабатты пленканың біртекті құрылымында мыстың сфералық нанобөлшектерінің біркелкі таралуын көрсетті. PEI-CuNPs оптикалық сипаттамалары мен гидродинамикалық өлшемдері нанобөлшектерінің пайда болуын көрсетеді. Өлшемдері 60-300 нм орташа мөлшері 100 нм дейін. Pei-CuNPs/PAMPS көп қабатты пленкасында біркелкі бөлінген мыс нанобөлшектері мембраналық катализ саласында, биочиптерді, сенсорлық мембраналарды және дәрі-дәрмектерді жеткізуді басқаруда қолдануға қызығушылық тудыруы мүмкін.

Түйін сөздер: полиэтиленимин; поли-2-акриламид-2-метил-1-натрий пропансульфонаты; PEI-Cu' ${ }^{2+}$ және PEI-CUNPs кешендері; қабатты тұндыру (LbL); көп қабатты жұқа PEI-CuNPs/PAMPS қабықшалары.
Получение и изучение физико-химических характеристик мультислойных полимерных композитов на основе стабилизированных поли(этиленимином) наночастиц меди и поли(2акриламид-2-метил-1пропансульфоната натрия)

Б.С. Селенова ${ }^{1}$, А.Е. Аязбаева ${ }^{1 *}$, А.В. Шахворостов ${ }^{2}$, С.К. Кабдрахманова ${ }^{1,3^{*}}$ С.3. Наурызова ${ }^{1}$, С.Е. Кудайбергенов

${ }^{1}$ Satbayev University, Алматы, Казахстан Институт полимерных материалов и технологий, Алматы, Казахстан ${ }^{3}$ Научный центр композитных материалов, Алматы, Казахстан *E-mail: sanaly33@mail.ru
Синтезированы мультислойные пленки с участием комплекса разветвленного полиэтиленимина (PEI) с наночастицами меди (PEI-CUNPS) и поли-2-акриламид-2 метил-1-пропансульфонатом натрия (PAMPSNa), нанесенные послойно методом layer-by-layer (LbL) на твердую подложку в кислой среде. Протонирование аминогрупп PEI в кислой среде увеличивает положительный заряд системы PEI-CuNPs до $+43,5 \mathrm{mV}$ и способствует образованию интерполиэлектролитного комплекса между положительно заряженным PEI-CuNPs и сильнозаряженным анионным полиэлектролитом PAMPS, Z-potential которого равен -141 mV. АСМ-изображения и микрофотографии СЭМ показали равномерное распределение сферических наночастиц меди в однородной структуре мультислойной пленки. Оптическая характеристики и гидродинамические размеры PEI-CuNPs указывают на образование наночастиц PEI-CUNPS с размерами 60-300 нм, со средним размером до $100 \mathrm{Hм}$ Наночастицы меди, равномерное распределенные в мүльтислойной пленке PEICuNPs/PAMPS могут представлять интерес для применения в области мембранного катализа, в создании биочипов, сенсорных мембран и контролируемой доставки лекарственных препаратов.

\section{Ключевые слова:}

полиэтиленимин

поли-2-акриламид-2-метил-1 пропансульфонат натрия; комплексы PEI-Cu²+ и PEI-CUNPs; послойное осаждение (LbL); мультислойные тонкие пленки PEI-CuNPs/PAMPS. 


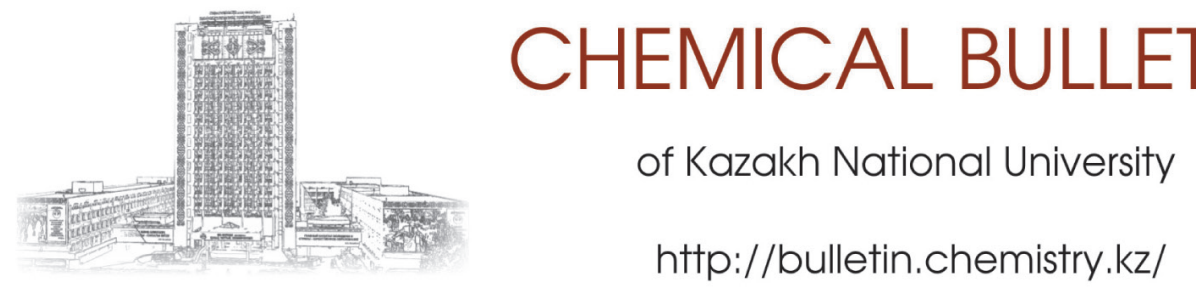

https://doi.org/10.15328/cb1235

\title{
Preparation and study of the physicochemical characteristics of multilayer polymer composites based on poly(ethyleneimine)-stabilized copper nanoparticles and poly(sodium 2-acrylamide-2-methyl-1-propanesulfonate)
}

\author{
B.S. Selenova ${ }^{\mathbb{D}}$, A.Ye. Ayazbayeva ${ }^{(\mathbb{D})}$, A.V. Shakhvorostov ${ }^{\mathbb{D}}$, S.K. Kabdrakhmanova ${ }^{1,3^{*}} \mathbb{( \mathbb { D }}^{\mathrm{D}}$, \\ S.Z. Nauryzova ${ }^{1}$, , S.E. Kudaibergenov ${ }^{2}$ (D)
}

${ }^{1}$ Satbayev University, 22a Satbayev str., 050013 Almaty, Kazakhstan

2Institute of Polymer Materials and Technology, 3/1 microdistrict "Atyrau 1", 050019 Almaty, Kazakhstan

${ }^{3}$ Scientific Center of Composite Materials, 79 Nurmakov str., 050026 Almaty, Kazakhstan

*E-mail: sanaly33@mail.ru

\section{Introduction}

One of the promising and intensively developing areas is the production of multilayer membranes and films by the layerby-layer (LbL) method, by embedding metal nanoparticles into their matrix to give them the desired properties and functions. Such thin-layer films have found wide application in the creation of biochips, sensor membranes, membrane nanocatalysts, for the stabilization of nanoparticles and controlled delivery of drugs, etc. The successful use of polyelectrolytes forming a complex due to covalent and hydrogen bonds, electrostatic interactions, and also due to molecular recognition made it possible to obtain new materials with unique physicochemical properties, for example, controlled thickness and morphology, uniform distribution of metal nanoparticles in the volume [1-3]. The purposeful introduction of metal nanoparticles into multilayer films makes it possible to use them as membrane nanocatalysts [4-6].

In [7-10], immobilization of mono- and bimetallic nanoparticles in the bulk of multilayer films was carried out to obtain effective nanocatalysts. It was found that the individual physicochemical properties of multilayer polymer composites depend on the choice of optimal blocks for assembling LbL capsules, the manufacturing technique, and the method of immobilization of various nanoparticles in the bulk of the films [7].

Pd nanoparticles attached to magnetic ferrite nanoparticles, supported on PAA and PEI, were used for the hydrogenation of olefin alcohols [8], and multilayer systems
PAA/PVP-Au, ethyl-3-thiophene acetate/PVP-Au [9] were used for the reduction of nitrophenol [10]. The regularities of the growth of multilayers of PEI/PAA, PEI/PSS, quaternized QPEI/ PAA and QPVP/PSS based on a polymer-metal complex (PMC) with copper and cobalt ions were determined, and the effect of the nature of polymers, $\mathrm{pH}$ of the medium, temperature, conditions of layer formation and absorption of metals on their surfaces for the formation of nanocatalysts were studied [11-13].

Of great scientific and practical interest are synthetic polyampholytes capable of existing in various conformational and phase states, depending on the change in temperature, $\mathrm{pH}$ of the medium, the type and concentration of low-molecularweight salt, and the thermodynamic quality of the solvent. Depending on the nature of the acidic and basic monomers, polyampholytes are divided into: weakly charged, highly charged polyampholytes and betaines. Representatives of fully charged macromolecules, highly charged polyampholytes, consist of charged cationic and anionic monomers and have the ability to retain charges in a wide range of $\mathrm{pH}$ values $[14,15]$. The behavior of highly charged polyampholytes depends on the composition of the copolymers and the distribution of monomer units [16]. The presence of permanent charges promotes the effective binding of metal ions, dyes and surfactants.

Copolymer of sodium 2-acrylamido-2methylpropanesulfonate (AMPSNa) is a typical representative of highly charged polyampholytes, which belongs to the less studied polymers. Recent studies show that the use of AMPSNa and ARTAC as a monomer makes it possible to synthesize 
polymer matrices with unique properties [17-20]. The importance of studies of polymers based on highly charged polyampholytes, in particular AMPSNa, is evidenced by a number of studies devoted to nanocomposite materials [21-25].

Studies on the complexation of highly charged polyelectrolytes with metal ions and the preparation of multilayer catalytic films by the LbL method have not been studied sufficiently and publications are of an episodic nature. Despite the wide range of polyelectrolytes, not all potentially applicable polymers are used to obtain multilayer nanocatalysts by LbL method.

In this work, a study was carried out on the creation of multilayers of a positively charged PEI-CUNPs complex and a negatively charged PAMPS polyelectrolyte. It is assumed that copper nanoparticles immobilized in PEI-CuNPs/PAMPS multilayers can be used as a catalytic center in the oxidation of organic substrates.

\section{Experiment}

\subsection{Materials}

Branched poly(ethylenimine) (PEI) with average-weight molecular weight $\mathrm{M}_{\mathrm{w}} \sim 25000$ and number-average molecular weight $M_{n} \sim 10000$ was purchased from Sigma-Aldrich $\mathrm{GmbH}$ (Figure 1).<smiles>NCCNCCN(CCNCCN(CCN)CCN(CCN)CCN)CCN(CCN)CCN</smiles>

Figure 1 - Branched PEI

2-Acrylamido-2-methyl-1-propanesulfonic acid sodium salt solution (AMPS) (50 wt. \% in aqueous solution) is the product of Sigma-Aldrich GmbH (Figure 2).

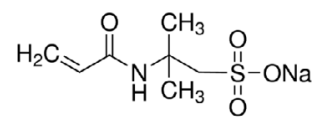

Figure 2 - AMPSNa

Copper (II) acetate monohydrate $\left[\mathrm{Cu}\left(\mathrm{COOCH}_{3}\right)_{2} \times \mathrm{H}_{2} \mathrm{O}\right]$ and ammonium persulfate (APS) were purchased from SigmaAldrich GmbH and Changzhou Qi Di Chemical Co (China) and used without further purification.

\subsection{Methods}

2.2.1 Preparation of PEI-CU ${ }^{2+}$ and PEI-CUNPs complexes PEI-Cu ${ }^{2+}$ and PEI-CuNPs complexes were obtained according to the method described in [26]. When the solution of copper (II) acetate was poured into the PEI solution slowly, with constant stirring, the solution acquired a dark blue color (Figure 3 , a). This indicated the formation of a $4: 1$ polymer-metal complex PEl-Cu${ }^{2+}$ which means that 4 monomer units of $\mathrm{PEI}$ coordinate with one copper ion. When sodium borohydride interacted with $\mathrm{PEI}-\mathrm{Cu}^{2+}$, the solution changed color from dark blue to dark brown (Figure 3b). The reduction of copper ions coordinated with PEI was accompanied by a short-term evolution of gaseous hydrogen. The resulting dark brown solution of PEI-CuNPs was dialyzed for 24 hours to remove low molecular weight impurities (Figure 3, c).

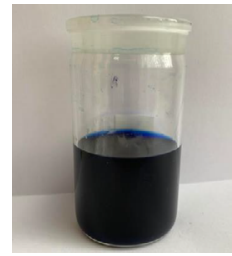

a)

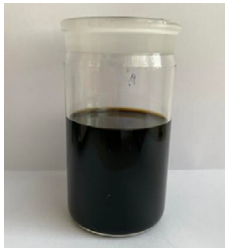

b)

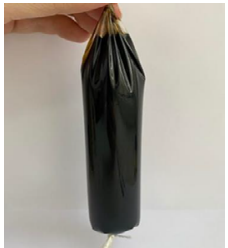

c)
Figure 3 - PEI - $\mathrm{Cu}^{2+}$ complex (a); PEI-CuNPs nanoparticles (b), dialysis of PEI-CuNPs nanoparticles (c)

The formation of four coordination complexes between the repeating units of $\mathrm{PEI}$ and bivalent copper ions, as well as the reduction of the $\mathrm{PEI}-\mathrm{Cu}^{2+}$ complex with sodium borohydride to the formation of $\mathrm{Cu}^{0}$ nanoparticles stabilized by PEI, can be represented by the following scheme

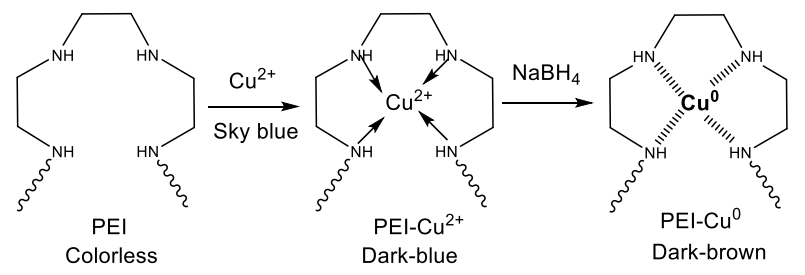

Scheme 1 - Scheme of the formation of the PEI-Cu ${ }^{2+}$ coordination complex and its reduction with sodium borohydride to the zero-valence state

2.2.2 Preparation of $\mathrm{SiO}_{2}$ substrate - SurfusNanoLane for the deposition of PEI-CUNPS/PAMPS multilayers

For the deposition of multilayers, a $\mathrm{SiO}_{2}$-SurfusNanoLane substrate was used, which was kept in Piranha solution (a mixture of hydrogen peroxide and sulfuric acid in a ratio of 1:4) for 24 hours to remove organic contaminants and increase the surface hydrophilicity. Then the substrate was washed with water and dried in a stream of nitrogen.

2.2.3 Layer-by-layer ( $L b L$ ) deposition

The LbL assembly process was performed by immersing a solid base in a dilute solution of a positively charged 
polyelectrolyte to adsorb the first monolayer, then immersing it in a negatively charged polyelectrolyte to obtain a second monolayer [27-29]. The multilayer deposition was carried out using ND-DC DipCoater Nadetech (Spain) rotary spray gun (Figure 4). Multilayers were formed on the surface of the substrates using PEI-CUNPs and PAMPS solutions with a concentration of $10^{-2} \mathrm{~mol} / \mathrm{L}$ at $\mathrm{pH}$ 4. The dipping procedure was carried out in the following order: 1) PEI-CuNPs solution; 2, 3) rinsing with distilled water; 4) PAMPS solution. In this way, PEI - CUNPs/PAMPS multilayers were obtained, consisting of 50 and 100 bilayers.

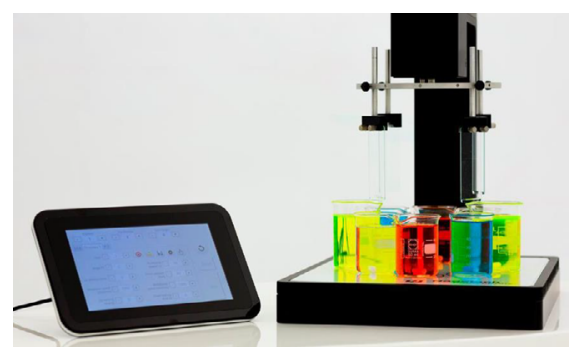

Figure 4 - Preparation of PEI-CuNPs/PAMPS multilayers using Rotary DipCoater

\subsubsection{Determination of the optical characteristics of PEI-} CuNPs solutions

The absorption spectra of PEI-CuNPs solutions in the ultraviolet and visible regions were measured on Specord 210 plusBU spectrophotometer (Germany, 2012). The quartz cells had an optical path length of 5 and $10 \mathrm{~mm}$. All measurements were carried out at $25^{\circ} \mathrm{C}$ and atmospheric pressure, at a wavelength of $200-800 \mathrm{~nm}$. In the spectrophotometric experiment, measurements were taken into account with a relative error of no more than $3 \%$.

2.2.5 Determination of the average hydrodynamic dimensions and zeta potential of PEI-Cu ${ }^{2+}$ and PEI-CUNPS solutions

The average hydrodynamic dimensions and zeta potential of $\mathrm{PEI}-\mathrm{Cu}^{2+}$ and PEI-CuNPs solutions were determined by dynamic laser light scattering on Malvern Zetasizer Nano ZS90 instrument (Malvern Instruments Ltd., UK). In the dynamic light scattering method, measurements were taken into account with a relative error of no more than $5 \%$.

\subsubsection{PAMPS identification}

The identification of PAMPS obtained by the method of radical polymerization was carried out by means of IR and NMR spectroscopy. IR spectra of PAMPS were recorded on Cary 660 FTIR IR Fourier spectrophotometer (Agilent Technologies, USA) in the frequency range $400-4000 \mathrm{~cm}^{-1}$. The limit of permissible error of the wave number scale is $\pm 0.1 \mathrm{~cm}^{-1}$.

${ }^{1} \mathrm{H}$ NMR spectra were recorded on Bruker BioSpinAvance III $500 \mathrm{MHz}$ NMR spectrometer (500 MHz, Germany) using deuterated water as a solvent. Chemical shifts are measured relative to the residual proton signals of the deuterated solvent.

2.2.7 Study of morphological, topographic and structural characteristics

SEM JSM-6390LV scanning electron microscope (Jeol, Japan) was used to study the surface morphology of the obtained multilayers deposited on $\mathrm{SiO}_{2}$-SurfusNanoLane substrate. The measurements were carried out in a high vacuum mode using a secondary electron detector at an accelerating voltage of $15 \mathrm{kV}$. Carbon was sprayed onto the surface of the samples using magnetron sputtering of carbon fiber to increase conductivity. The samples were mounted on aluminum rods with conductive carbon tape.

The topographic characteristics of the multilayer were obtained using scanning probe microscopy SmartSPM-1000 (Russia) with a scanning range of $100 \times 100 \times 15$ microns. Scanner resonant frequencies $>7 \mathrm{kHz}$ in $\mathrm{XY}$ and $>15 \mathrm{kHz}$ in $\mathrm{Z}$.

\section{Results and Discussion}

\subsection{Synthesis and characterization of PAMPS}

PAMPS was obtained by radical polymerization of a $30 \%$ aqueous AMPS solution in the presence of $0.25 \%$ APS at $50^{\circ} \mathrm{C}$ for $4 \mathrm{~h}$. Unreacted monomers were removed by dialysis through a membrane in a container with distilled water with a volume of $5 \mathrm{~L}$, followed by drying in an oven for $5 \mathrm{~h}$, in a refrigerator for 3 $\mathrm{h}$, and in a lyophilic unit for $3 \mathrm{~h}$. Figure 5 shows the IR spectrum of PAMPS obtained by the method of radical polymerization.

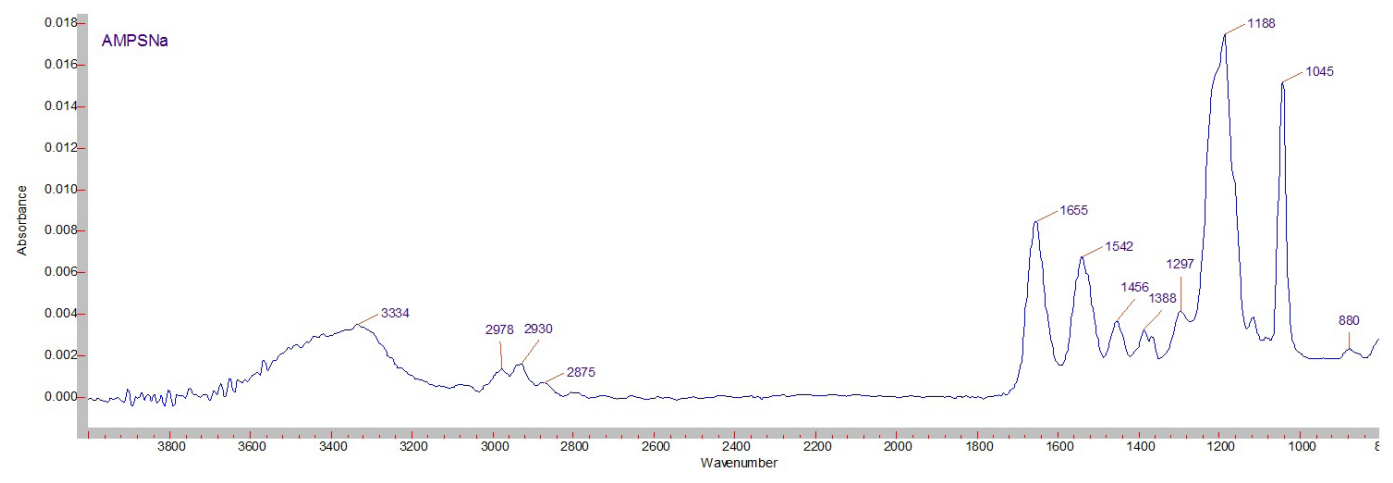

Figure $\mathbf{5}$ - IR absorption spectrum of PAMPS 


\section{Avance 111500 1H PAMPSNa in D2O}

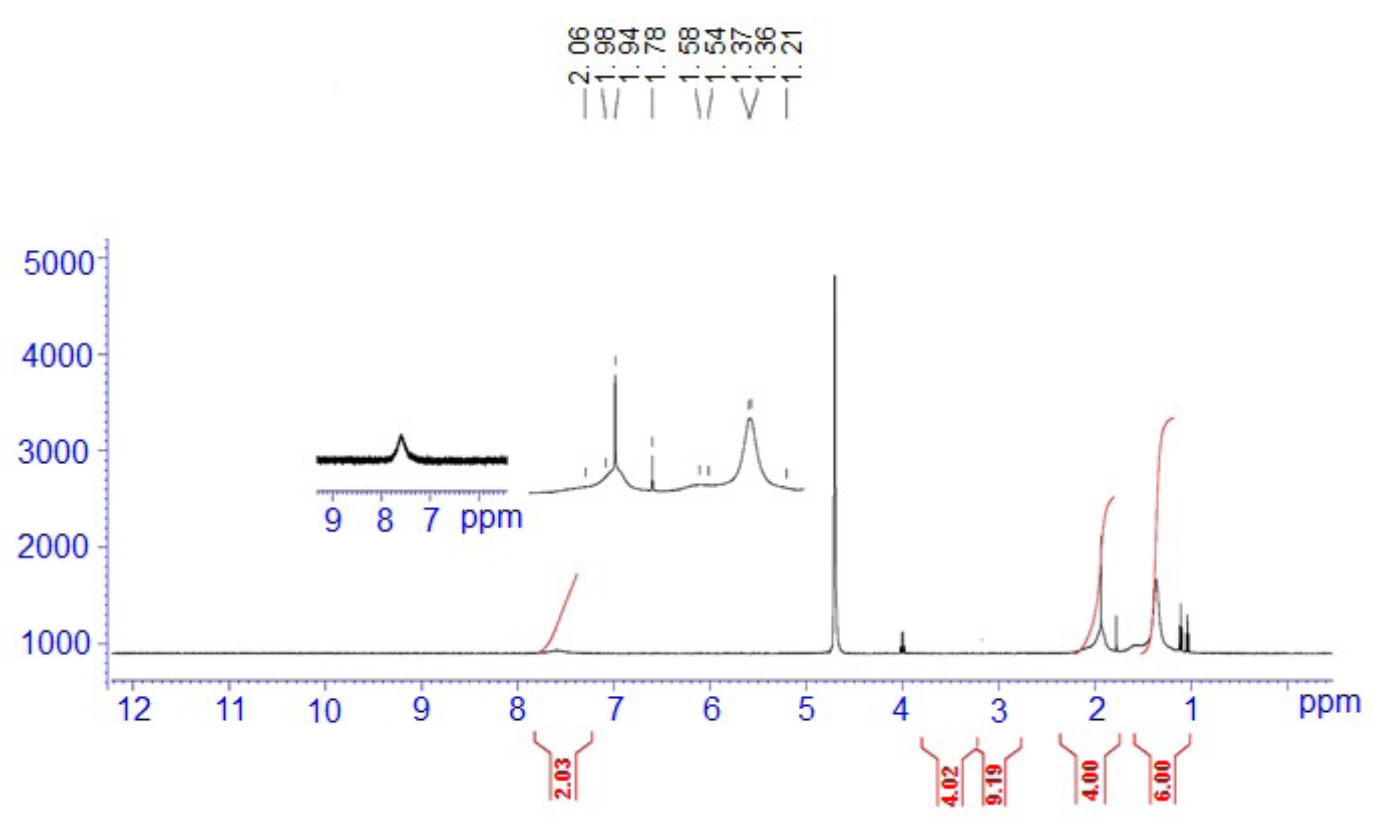

Figure $6-{ }^{1} \mathrm{H}$ NMR spectra of PAMPS

The absorption spectra of PAMPS are characterized by the corresponding peaks of bending and stretching vibrations of functional groups. The broad absorption band at $3334 \mathrm{~cm}^{-1}$ corresponds to stretching vibrations of $\mathrm{N}-\mathrm{H}$ groups. Stretching vibrations of the carbonyl group of the primary amide appear at $1655 \mathrm{~cm}^{-1}$. Bending vibrations of $\mathrm{C}-\mathrm{N}$ and $\mathrm{C}-\mathrm{NH}$ amino groups appear at $1542 \mathrm{~cm}^{-1}$. The absorption bands at $1388 \mathrm{~cm}^{-1}$ and $1297 \mathrm{~cm}^{-1}$ correspond to the $-\mathrm{CH}_{2}$ - and $\mathrm{CH}$ groups of the polymer ridge. The characteristic $\mathrm{S}=\mathrm{O}$ absorption bands appear in the regions of $1045 \mathrm{~cm}^{-1}$ and $1188 \mathrm{~cm}^{-1}[17,30,31]$.

The structure of PAMPS was also identified by ${ }^{1} \mathrm{H}$ NMR spectroscopy (Figure 6). The data obtained show the presence of $6 \mathrm{H}$ protons of 2 methyl groups, resonating in the region of $1.36 \mathrm{ppm}$, which confirms the linear structure of PAMPS and is in good agreement with the data of [32].

3.2 UV-Vis absorption spectra of PEI-CUNPs before and after dialysis

Figure 7 shows the results of a study of a colloidal solution of PEI-CUNPs by UV-Vis spectroscopy before and after dialysis. According to [33], the absorption spectrum of a copper acetate solution is characterized by a maximum at a wavelength of $\lambda=$ $800 \mathrm{~nm}$. In the spectrum of the PEl solution, no maxima are observed in the wavelength range of 200-1000 $\mathrm{nm}$. When a copper acetate solution is added to an aqueous PEI solution, a maximum appears in the spectrum at a wavelength of $\lambda=620$ $\mathrm{nm}$ and a maximum characteristic of a pure copper solution disappears, which indicates the formation of PEI- $\mathrm{Cu}^{2+}$ complex.
The formation of PEI-CuNPs nanoparticles is characterized by the appearance of an absorption band at 535-540 nm. After dialysis for $24 \mathrm{~h}$, the absorption spectra of PEI-CuNPs did not undergo significant changes, and the maximum of the absorption band at $540 \mathrm{~nm}$ remained practically unchanged for several months. This indicates the high stability of PEI-CuNPs nanoparticles. The decrease in the spectrum intensity after dialysis is associated with the removal of small nanoparticles, as demonstrated in the next section.

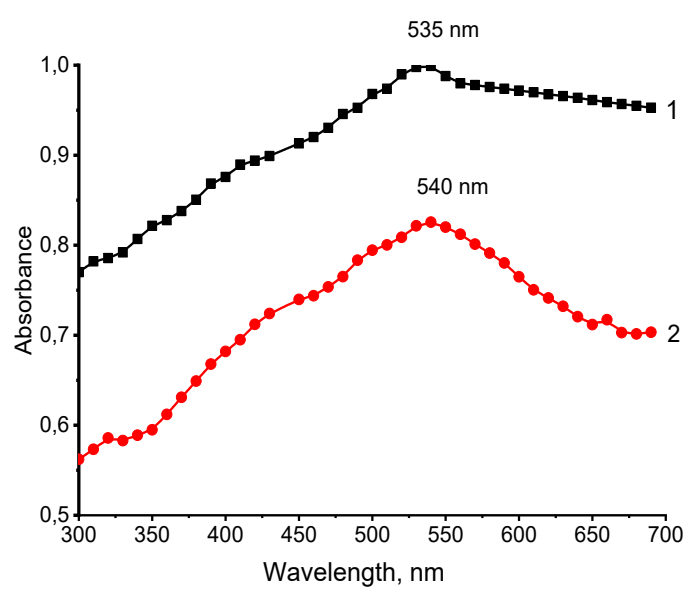

Figure 7 - UV-Vis absorption spectra of the colloidal PEI-CUNPS solution before (1) and after (2) dialysis for $24 \mathrm{~h}$ 
3.3 Average hydrodynamic dimensions and zeta potential of PEI and PEI-CUNPs solutions

Figure 8 shows a histogram of the numerical size and $\zeta$-potential distribution of the pure PEI solution obtained by dynamic light scattering. The histogram of the hydrodynamic particle size distribution of pure PEI is mainly divided into two ranges with an average particle size of 3-200 $\mathrm{nm}$ and a range of size scatter of 3-4 $\mathrm{nm}$ and $200 \mathrm{~nm}$, respectively (Figure 8, a). More than $70 \%$ of them fall within the $3-4 \mathrm{~nm}$ size range. The zeta potential of the pure $\mathrm{PEI}$ solution is positive and is $+2.95 \pm$ $0.1 \mathrm{mV}$ (Figure 8, b).

The distribution of PEI-CuNPs nanoparticles before dialysis is bimodal. The average hydrodynamic sizes of nanoparticles vary from 65 to $198 \mathrm{~nm}$ (Figure 9, a). In this case, particles with a size of $198 \mathrm{~nm}$ prevail, the amount of which is $96 \%$. The zeta potential of the PEI-CUNPs solution before dialysis is $+32.9 \pm 1.6$ $\mathrm{mV}$ (Figure 9, b).
The histogram of the hydrodynamic size distribution of PEI-CUNPs nanoparticles with an average particle size of $100 \mathrm{~nm}$ and a particle scatter range of $60-300 \mathrm{~nm}$ is shown in Figure 10, a. It can be seen that the distribution of copper nanoparticles in the PEI-CuNPs solution after dialysis became monomodal, i.e. it can be assumed that only large PEI-CuNPs nanoparticles remained in the solution, while small nanoparticles were washed out. The solution has a positive zeta potential corresponding to $+43.5-2.04 \mathrm{mV}$ (Figure 10, b), since copper nanoparticles are chemisorbed with a positively charged polyelectrolyte $-\mathrm{PEI}$ at $\mathrm{pH}=4.0$.

This also indicates the stability of the aqueous suspension of PEI-CuNPs, which is provided due to the prevalence of electrostatic repulsion between positively charged particles reducing the possibility of aggregation. The positive charge of the PEI-CuNPs means it will form a polyionic complex with the negatively charged PAMPS.

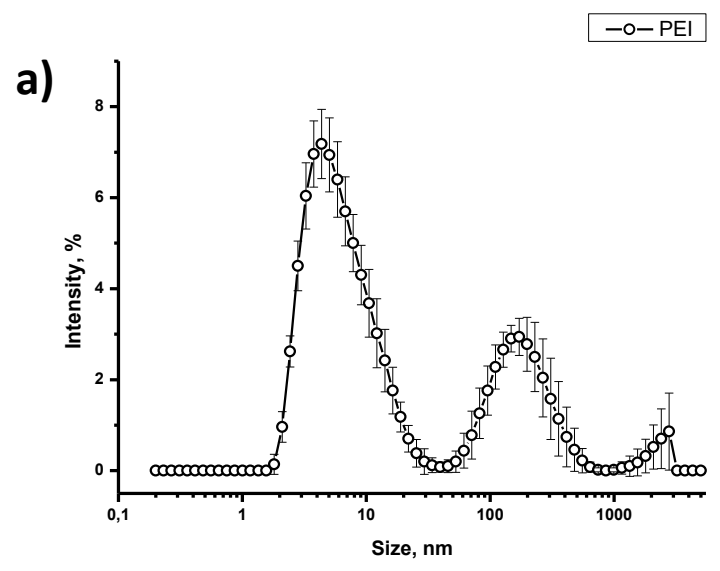

b)

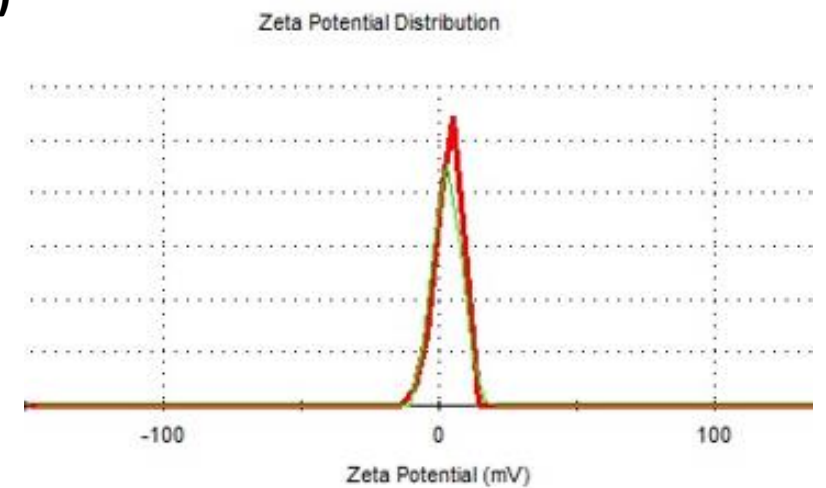

Figure 8 - Histogram of PEI distribution by hydrodynamic dimensions (a) and $\zeta$-potential of the solution (b)
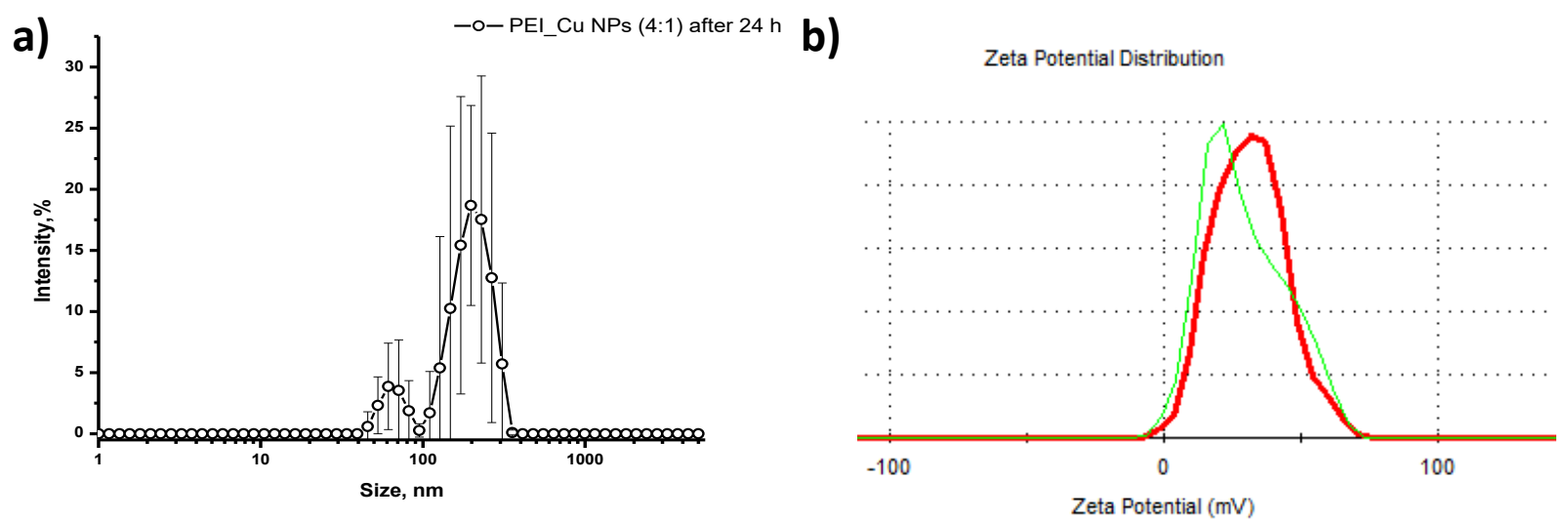

Figure 9 - Histogram of the PEI-CuNPs distribution by hydrodynamic dimensions (a) and $\zeta$-potential of the solution (b) before dialysis 

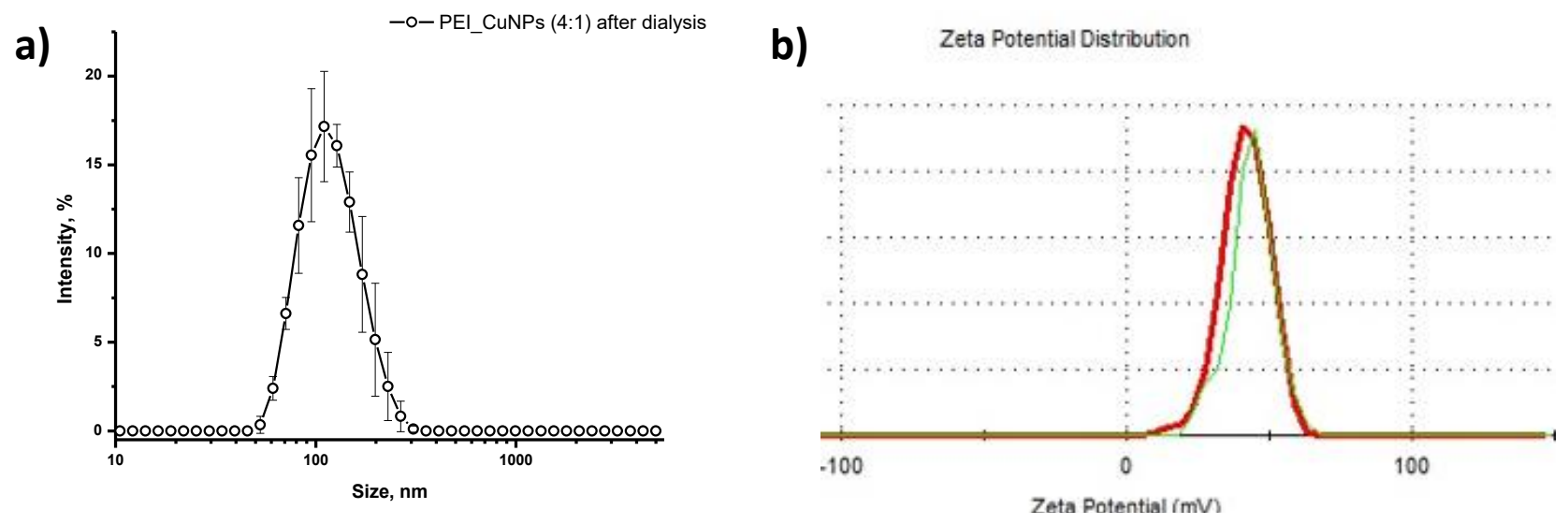

Figure 10 - Histogram of the PEI-CUNPs distribution by hydrodynamic dimensions (a) and $\zeta$-potential of the solution (b) after dialysis

3.4 Preparation of PEI-CuNPs/PAMPS multilayers

In order to create multilayer films by the LbL method, we used solutions of a positively charged polyelectrolyte - PEICuNPs and a negatively charged polyelectrolyte - sodium poly2-acrylamide-2-methyl-1-propanesulfonate (PAMPSNa). $\mathrm{SiO}_{2}$ SurfusNanoLane was used as a substrate, on which positively charged PEI-CuNPs nanoparticles $(\zeta=+43.5 \pm 2.04 \mathrm{mV})$ and negatively charged PAMPS $(\zeta=-141 \pm 7 \mathrm{mV})$ were alternately deposited. As can be seen from Fig. 11, the substrate is coated uniformly with PEI-CUNPs/PAMPS multilayers, consisting of 50 (Figure 11, a) and 100 layers (Figure 11, b) painted in a saturated blue color.

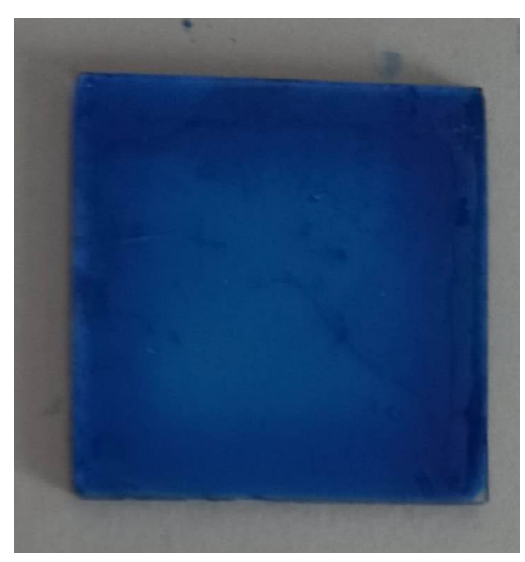

a)

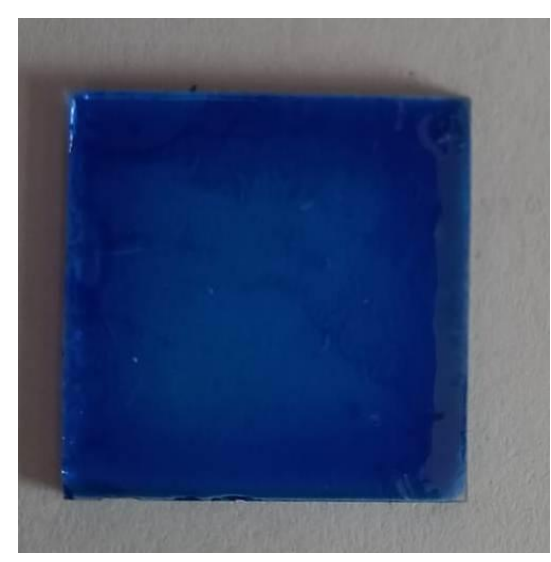

b)

Figure 11 - Multilayers: a - PEI-CUNPs/PAMPS (50 layers); b - PEI-CuNPs/PAMPS (100 layers) applied to the plate using the layer-by-layer method

Figure 12 shows AFM images of PEI-CUNPs/PAMPSNa multilayer films (50 layers) deposited on a silicon substrate. It is seen that the surface of multilayer films is sufficiently smooth and porous. The pores are spherical. A granular morphology with a developed surface structure with a grain size of 50-130 $\mathrm{nm}$ is observed. The roughness of multilayer PEI-CUNPs/PAMPS films is small and averages $\geq 20 \mathrm{~nm}$. The formation of a uniform surface of multilayers is apparently associated with the formation of interpolyelectrolyte complexes with positively charged PEI-CuNPs nanoparticles and negatively charged PAMPS macromolecules stabilized by polyionic contacts.

The data of the atomic force microscopy are confirmed by the results of the scanning electron microscope (Figure 13). In homogeneous multilayers, evenly distributed and isolated copper nanoparticles, which have a spherical shape, can be seen. 

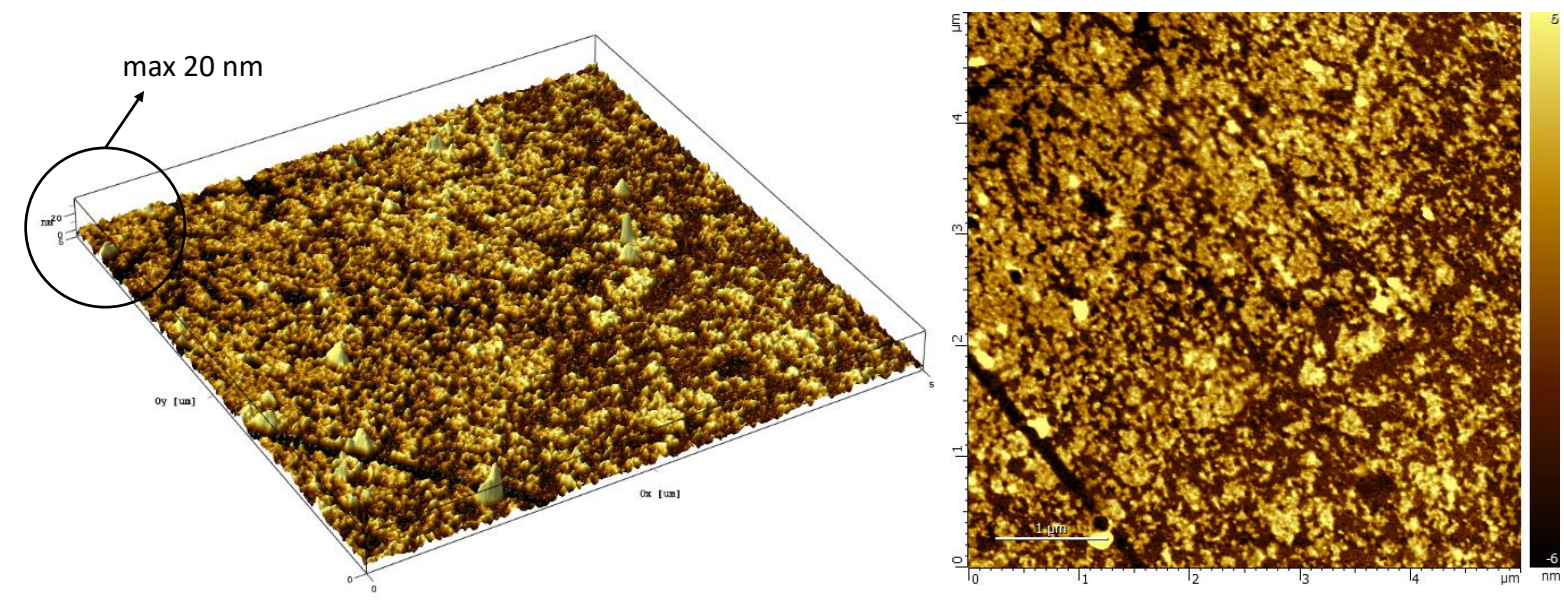

Figure 12 - Surface topography of PEI-CUNPs/PAMPS multilayer film (50 layers)
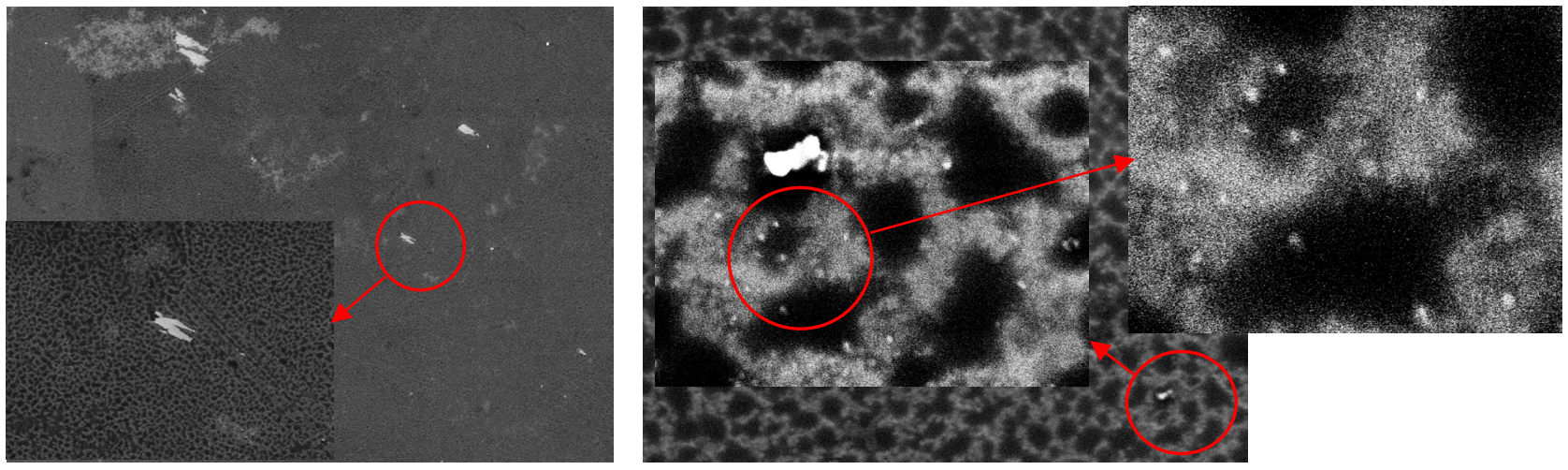

Figure 13 - SEM micrographs of PEI-CUNPs/PAMPS multilayer film

\section{Conclusion}

Multilayered thin films composed of PEI-CuNPs/PAMPS have been obtained by layer-by-layer deposition of positively charged PEI-CuNPs and negatively charged PAMPS on the surface of $\mathrm{SiO}_{2}$. In aqueous solution PEI, PEI-Cu${ }^{2+}$ and PEI-CUNPS were characterized by UV-Vis spectroscopy, DLS, and zetapotential. In solid state multilayers of PEI-CUNPs/PAMPS were studied by AFM and SEM. It was found that nanoparticles of copper are uniformly distributed within multilayers and in perspective can be used as membrane catalysts for oxidation of organic substrates.

\section{Acknowledgments}

This research was funded by the Science Committee of the Ministry of Education and Science of the Republic of Kazakhstan (Grant No. AP08957241).

\section{References (GOST)}

1 Stockton W.B., Rubner M.F. Molecular-level processing of conjugated polymers. 4. Layer-by-layer manipulation of polyaniline via hydrogen-bonding interactions // Macromolecules. - 1997. - Vol.30(9). - P.2717-2725.

2 Tong W.J., Gao C.Y., Möhwald H. Manipulating the properties of polyelectrolyte microcapsules by glutaraldehyde cross-linking // Chemistry of Materials. - 2005. - Vol.17(18). - P.4610-4616.

3 Kida T., Mouri M., Akashi M. Fabrication of hollow capsules composed of poly(methyl methacrylate) stereocomplex films // 
Angewandte Chemie International Edition. - 2006. - Vol.118(45). - P.7696-7698.

4 Richardson J.J., Cui J., Bjornmalm M., et al. Innovation in layer-by-layer assembly // Chemical Reviews. - 2016. - Vol.116. P.14828-14867.

5 Dhar J., Patil S. Self-assembly and catalytic activity of metal nanoparticles immobilized in polymer membrane prepared via layer-by-layer approach // ACS Applied Materials \& Interfaces. - 2012. - Vol.4. - P.1803-1812.

6 Kudaibergenov S., Tatykhanova G., Bakranov N., Tursunova R. Layer-by-layer thin films and coatings containing metal nanoparticles in catalysis. Chapter 8 in Thin Film Processes - Artifacts on Surface Phenomena and Technological Facets / Ed. by J. Thirumalai. - InTech, 2017. - P.147-164.

7 Xiao F.-X., Pagliaro M., Xu Y.-J., et al. Layer-by-layer assembly of versatile nanoarchitectures with diverse dimensionality: a new perspective for rational construction of multilayer assemblies // Chemical Society Reviews. - 2016. - Vol.45. - P.3088-3121.

8 Wang Y., Lee J.-K. Recyclable nano-size Pd catalyst generated in the multilayer polyelectrolyte films on the magnetic nanoparticle core // Journal of Molecular Catalisis A: Chemical. - 2007. - Vol.263. - P.163-168.

9 Jiang Y., Shen Y., Wu P. Self-assembly of multilayer films containing gold nanoparticles via hydrogen bonding // Journal of Colloid and Interface Science. - 2008. - Vol.319. - P.398-405.

10 Dhar J., Patil S. Self-assembly and catalytic activity of metal nanoparticles immobilized in polymer membrane prepared via layer-by-layer approach // ACS Applied Materials \& Interfaces. - 2012. - Vol.4. - P.1803-1812.

11 Mentbayeva A.A., Koshikova A.O., Karagulanova A.S., Seilkhanova G.A., Ospanova A.K. Regularities of the processes of complexation of $\mathrm{Cu}^{2+}$ and $\mathrm{Co}^{2+}$ ions with polyethyleneimine and polyvinylpyridine // News of NAS RK. Series of Chemistry [lzvestiya NAN RK. Seriya Khimicheskaya]. - 2012. - Is.2(392). - P.61-66.

12 Mentbayeva A.A., Ospanova A.K., Tashmuhambetova Z.H., Sokolova V.V., Sukhishvili S. Polymer metal complexes in polyelectrolyte multilayer films as catalysts for oxidation of toluene // Langmuir - 2012. - Vol.28. - P.11948-11955.

13 Mentbayeva A.A., Ospanova A.K. Polymer metal complexes usage of layer-by-layer method for obtaining polyelectrolyte multilayer films containing transition metal cations // Eurasian Chemico-Technological Journal. - 2012. - Vol.14. - P.169-176.

14 Salamone J.C. Functional Properties of Teff and Oat Composites // Polymeric Materials Encyclopedia. CRC Press, Boca Raton. - 1996. - Vol.6(17). - P.5476-5488.

15 Nair A. K. N., Jimenez A. M., Sun S. Y. Complexation behavior of polyelectrolytes and polyampholytes // Journal of Physical Chemistry B. - 2017. - Vol.121(33). - P.7987-7998.

16 Bekturov E. A., Kudaibergenov S.E. Physicochemical properties of polyampholytes in solutions // Makromolekulare ChemieMacromolecular Symposia. - 1989. - Vol.26. - P.281-295.

17 Kudaibergenov S.E. Macromolecular complexes of polyampholytes // Pure and Applied Chemistry. - 2020. - Vol.92(6). - P.839852.

18 Ulrich S., Seijo M., Carnal F. et al. Formation of complexes between nanoparticles and weak polyampholyte chains. Monte Carlo simulations // Macromolecules. - 2011. - Vol.44. - P.1661-1670.

19 Kudaibergenov S., Nuraje N. Intra- and interpolyelectrolyte complexes of polyampholytes // Polymers. - 2018. - Vol.10. ID1146.

20 Nakahata R., Yusa S.-I. Solution properties of amphoteric random copolymers bearing pendant sulfonate and quaternary ammonium groups with controlled structures // Langmuir. - 2018. - Vol.35(5). - P.1690-1698.

21 Toleutay G., Su E., Kudaibergenov S. et al. Highly stretchable and thermally healable polyampholyte hydrogels via hydrophobic modification // Colloid and Polymer Science. - 2020. - Vol.298. - P.273-284.

22 Atta A.M., Moustafa Y.M., Al-Lohedan H.A. et al. Methylene blue catalytic degradation using silver and magnetite nanoparticles functionalized with a poly(ionic liquid) based on quaternizeddialkylethanolamine with 2-acrylamido-2-methylpropane sulfonateco-vinylpyrrolidone // ACS Omega. - 2020. - Vol.5. - P.2829-2842.

23 Ohlemacher A., Candau F., Munch J.P. et al. Aqueous solution properties of polyampholytes: Effect of the net charge distribution // Journal of Polymer Science Part B-Polymer Physics. - 1996. - Vol.34(16). - P.2747-2757.

24 Kudaibergenov S.E. Macromolecular complexes of polyampholytes // Pure and Applied Chemistry. - 2020. - Vol.92. - P.839858.

25 Kudaibergenov S. Synthetic and natural polyampholytes: Structural and behavioral similarity // Polymers for Advanced Technologies. - 2020. - Vol.32(3). - P.906-918.

26 Kalidhasan S., Ben-Sasson M., Dror I. et al. Oxidation of aqueous organicpollutants using a stable copper nanoparticle suspension // Canadian Journal of Chemical Engineering. - 2017. - Vol.95. - P.343-352.

27 Fujita S., Shiratori S. Waterproof anti reflection films fabricated by layer-by-layer adsorption process // Japanese Journal of Applied Physics. - 2004. - Vol.43. - P.2346-2351.

28 Kim J.H., Kim S.H., Shiratori S. Fabrication of Nanoporous and hetero structure thin film via a layer-by-layer self assembly method for a gas sensor // Sensors and Actuators. - 2004. - Vol.102. - P.241-247.

29 Decher G., Hong J. Buildup of ultrathin multilayer films by a self-assembly process: II. Consecutive adsorption of anionic and 
cationic bipolar amphiphiles and polyelectrolytes on charged surfaces // Berichte der Bunsen-Gesellschaft. - 1991. - Vol.95. P.1430-1434.

30 Li Z., Pu X., Tao H., et al. Synthesis and properties of acrylamide2-acrylamido-2-methypropane sulfonic acidsodium styrene sulfonate $\mathrm{N}$-vinyl pyrrolidonequadripolymer and its reduction of drilling fluidfiltration at high temperature and high salinity // Journal of Polymer Engineering. - 2014. - Vol.34(2). - P.125-131.

31 Atta A.M., Al-Hussain S.A., Al-Lohedan H.A., et al. Application of new sodium vinyl sulfonate -co 2-acrylamido-2-methylpropane sulfonic acid sodium salt - magnetite cryogel nanocomposites for fast methylene blue removal from industrial waste water // Nanomaterials. - 2018. - Vol.8(11). - P.878-894.

32 Dehant I., Dants R., Kimmer V., Shmolke R. Infrared spectroscopy of polymers. - M.: Khimiya, 1976. (In Russian)

33 Ustyakina D.R., Chevtaev A.S., Tabunshchikov A.I. et al. Complexes of polyethyleneimine with $\mathrm{Cu}^{2+}$ ions in aqueous solutions as precursors for obtaining nanosized copper particles // High-molecular compounds. Series B. - 2019. - Vol.61, Is.3. - P.179-183.

\section{References}

1 Stockton WB, Rubner MF (1997) Macromolecules 30 (9):2717-2725. http://doi.org/10.1021/ma9700486

2 Tong WJ, Gao CY, Möhwald H (2005) Chem Mater 17(18):4610-4616. https://doi.org/10.1021/cm0507516

3 Kida T, Mouri M, Akashi M (2006) Angew Chem Int Edit 118(45):7696-7698. http://doi.org/10.1002/anie.200602116

4 Richardson JJ, Cui J, Bjornmalm M, et al (2016) Chem Rev 116:14828-14867. http://doi.org/10.1021/acs.chemrev.6b00627

5 Dhar J, Patil S (2012) ACS Appl Mater Inter 4:1803-1812. http://doi.org/10.1021/am300068e

6 Kudaibergenov S, Tatykhanova G, Bakranov N, Tursunova R (2017) Artifacts on Surface Phenomena and Technological Facets. IntechOpen, UK. P.147-164. http://doi.org/10.5772/64990

7 Xiao FX, Pagliaro M, Xu YJ, et al (2016) Chem Soc Rev 45:3088-3121. http://doi.org/10.1039/c5cs00781j

8 Wang Y, Lee JK (2007) J. Molecular Catalisis A: Chemical 263:163-16. http://doi.org/10.1016/j.molcata.2006.08.069

9 Jiang Y, Shen Y, Wu P (2008) J. Colloid and Interface Science 319:398-405. http://doi.org/10.1016/j.jcis.2007.12.020

10 Dhar J, Patil S (2012) Appl. Mater. Interfaces 4:1803-1812. http://doi.org/10.1021/am300068e

11 Mentbayeva AA, Koshikova AO, Karagulanova AS, et al (2012) News of NAS RK. Series of Chemistry [Izvestiya NAN RK. Seriya Khimicheskaya] 2(392):61-66. (In Russian)

12 Mentbayeva AA, Ospanova AK, Tashmuhambetova ZH, et al (2012) Langmuir 28:11948-11955. https://doi.org/10.1021/ la3025342

13 Mentbayeva AA, Ospanova AK (2012) Eurasian Chem Technol J 14:169-176. https://doi.org/10.18321/ectj110

14 Salamone JC (1996) Polymeric Materials Encyclopedia 6(17):5476-5488.

15 Nair AKN., Jimenez AM, Sun SY (2017) J Phys Chem B 121(33):7987-7998. https://doi.org/10.1021/acs.jpcb.7b04582

16 Bekturov EA, Kudaibergenov SE (1989) J Macromol Sci-Pol R 26:281-295. https://doi.org/10.1080/07366579008050910

17 Kudaibergenov SE (2020) Pure Appl Chem 92(6):839-852. https://doi.org/10.1515/pac-2019-1104

18 Ulrich S, Seijo M, Carnal F, et al (2011) Macromolecules 44:1661-1670. https://doi.org/10.1021/ma1024895

19 Kudaibergenov S, Nuraje N (2018) Polymers 10:1146. https://doi.org/10.3390/polym10101146

20 Nakahata R, Yusa S-I (2018) Langmuir 35 (5):1690-1698. https://doi.org/10.1021/acs.langmuir.7b03785

21 Toleutay G, Su E, Kudaibergenov S et al (2020) Colloid Polym Sci 298:273-284. https://doi.org/10.1007/s00396-020-04605-8

22 Atta AM, Moustafa YM, Al-Lohedan HA, et al (2020) ACS Omega 5:2829-2842. https://doi.org/10.1021/acsomega.9b03610

23 Ohlemacher A, Candau F, Munch JP, et al (1996) J Polym Sci Pol Lett 34(16):2747-2757. https://doi.org/10.1002/(SICI)1099-

0488(19961130)34:16<2747::AID-POLB7>3.0.CO;2-M

24 Kudaibergenov SE (2020) Pure Appl Chem 92:839-858. https://doi.org/10.1515/pac-2019-1104

25 Kudaibergenov S (2020) Polym Advan Technol 32(3):906-918. https://doi.org/10.1002/pat.5145

26 Kalidhasan S, Ben-Sasson M, Dror I et al (2017) Can J Chem Eng 95:343-352. https://doi.org/10.1002/cjce.22652

27 Fujita S, Shiratori S (2004) Jpn J Appl Phys 43:2346-2351. https://doi.org/10.1143/JJAP.43.2346

$28 \mathrm{Kim} \mathrm{JH}, \mathrm{Kim} \mathrm{SH}$, Shiratori S (2004) Sensor Actuat B-Chem 102:241-247. https://doi.org/10.1016/j.snb.2004.04.026

29 Decher G, Hong J (1991) Berichte der Bunsengesellschaft für physikalische Chemie 95:1430-1434. http://doi.org/10.1002/ bbpc.19910951122

30 Li Z, Pu X, Tao H, et al (2014) J Polym Eng 34(2):125-131. https://doi.org/10.1515/polyeng-2013-0257

31 Atta AM, Al-Hussain SA, Al-Lohedan HA, et al (2018) Nanomaterials 8(11):878-894. https://doi.org/10.20944/ preprints201809.0402.v1

32 Dehant I, Dants R, Kimmer V, Shmolke R (1976) Infrared spectroscopy of polymers [Infrakrasnaya spektroskopiya polimerov]. Khimiya, Moscow, USSR. (In Russian)

33 Ustyakina DR, Chevtaev AS, Tabunshchikov Al, et al (2019) Polym Sci Ser B+ 61(3):179-183. https://doi.org/10.1134/ S1560090419030151 